\title{
Marketing Integration in Cross-Border Mergers and Acquisitions: Conceptual Framework and Research Propositions
}

\section{Rudolf R Sinkovics • Mohd Haniff Jedin • Noemi Sinkovics}

\section{This is a pre-print (non-publisher's document). Please cite the article in press as:}

Sinkovics, Rudolf R, Mohd Haniff Jedin, and Noemi Sinkovics (2013), "Marketing integration in cross-border mergers and acquisitions: Conceptual framework and research propositions," European Journal of International Management, accepted for publication and forthcoming. ( available: http://www.manchester.ac.uk/escholar/uk-acman-scw:205135 ).

\section{Abstract and Key Results}

- Cross-border mergers and acquisitions $(M \& A s)$ are strategic business expansions across national boundaries, which can prove rather problematic and complex. The most challenging part of the process is the integration of two different firms that feature different management styles and departmental practice. Once the integration seeps deeper into functional levels, strategic-level $M \& A$ commitment is faced with operational implementation issues. The marketing departmental function is usually heavily involved in this integration process. Research on marketing integration in relation to $M \& A s$ has paid little attention to the process of combining similar resources from two similar departments, particularly in the cross-border M\&A context. Furthermore, existing research does not clearly demonstrate the success factors that contribute to the marketing integration process in $M \& A s$. Hence, this paper discusses the phenomenon of marketing integration in the cross-border $M \& A$ context. Collaboration, interaction, marketing synergy and redeployment of marketing resources are proposed as antecedents to the integration. Drawing from the extant literature, propositions are developed, and mechanisms to improve $M \& A$ integration performance are elaborated.

\section{Key Words}

Mergers and Acquisitions, Functional integration, Marketing, Literature review

\section{Authors}

Rudolf R. Sinkovics $(\square)$

Professor of International Business

Comparative \& International Business Research Centre (CIBER)

Rudolf.Sinkovics@manchester.ac.uk,www.manchester.ac.uk/research/rudolf.sinkovics

Mohd Haniff Jedin

University Utara Malaysia 
06010 Sintok Kedah, Malaysia

haniff06@yahoo.com

Noemi Sinkovics

Lecturer in International Business

Comparative \& International Business Research Centre (CIBER)

The University of Manchester, Manchester Business School, Manchester, UK.

Noemi.Sinkovics@manchester.ac.uk,

www.manchester.ac.uk/research/mbs/noemi.sinkovics

\section{Author profiles}

Rudolf R. Sinkovics is Professor of International Business at Manchester Business School, U.K. He has published on inter-organizational governance, the role of ICT in firm internationalization and research methods in international business. Recent work focuses on rising powers, emerging markets firms and drivers of economic change. He received his $\mathrm{PhD}$ from Vienna University of Economics and Business (WU), Austria in 1998. His work appeared in International Business and International Marketing journals such as Journal of International Business Studies, Management International Review, Journal of World Business, International Business Review, and International Marketing Review. Born in Austria, he now lives and works in Manchester, UK.

Mohd Haniff Jedin is Associate Professor of International Business at University Utara, Malaysia. He received $\mathrm{PhD}$ from The University of Manchester. His research focuses on international business and mergers and acquisitions in cross-border relationships.

Noemi Sinkovics is Lecturer in International Business at Manchester Business School. She holds a PhD from the University of Manchester and a Master's degree from the Vienna University of Economics and Business (WU-Wien). Her research focuses on International Entrepreneurship, ICT, and Economic Development issues and she contributes actively to research projects in the MBS-CIBER. She has contributed book chapters to editions of International Business books and published in International Business Review, International Marketing Review and Journal of Business Research. She is Hungarian and now lives in Manchester, UK.

\section{Acknowledgements}

The authors are grateful for the helpful comments from Shlomo Tarba and Yaakov Weber on earlier versions of this manuscript. We also appreciate supportive comments from the editor Vlad Vaiman and from anonymous reviewers. 


\title{
Marketing Integration in Cross-Border Mergers and Acquisitions: Conceptual Framework and Research Propositions
}

\begin{abstract}
Cross-border mergers and acquisitions (M\&As) are strategic business expansions across national boundaries, which can prove rather problematic and complex. The most challenging part of the process is the integration of two different firms that feature different management styles and departmental practice. Once the integration seeps deeper into functional levels, strategic-level M\&A commitment is faced with operational implementation issues. The marketing departmental function is usually heavily involved in this integration process. Research on marketing integration in relation to M\&As has paid little attention to the process of combining similar resources from two similar departments, particularly in the cross-border M\&A context. Furthermore, existing research does not clearly demonstrate the success factors that contribute to the marketing integration process in M\&As. Hence, this paper discusses the phenomenon of marketing integration in the cross-border M\&A context. Collaboration, interaction, marketing synergy and redeployment of marketing resources are proposed as antecedents to the integration. Drawing from the extant literature, propositions are developed, and mechanisms to improve M\&A integration performance are elaborated.
\end{abstract}

KEYWORDS: Mergers and Acquisitions, Functional integration, Marketing, Literature review

\section{Introduction}

Cross-border mergers and acquisitions (M\&As) are very intricate phenomena compared to domestic M\&As (Stahl and Mendenhall, 2005). Despite their complexity, cross-border M\&As enjoy sizable popularity and are considered a viable means for international growth. While this stands in sharp contrast to their high failure rates (Schoenberg, 2006), cross-border M\&As are serving as an alternative to other forms of internationalization (Sinkovics, Zagelmeyer, and Kusstatscher, 2011). Indeed, recent metaanalytic studies are not able to establish clearly the predictors for M\&A success or failure (Stahl and Voigt, 2008) and evidence from past research suggests that most cross-border M\&As take substantial time to show benefits (Agrawal, Ferrer, and West, 2011), only exhibit average performance results or fail altogether (Marks and Mirvis, 2011a). Moreover, research on M\&A is arguably rather fragmented and mostly dispersed in various disciplines of business and management studies, leaving potential gaps that need to be addressed (Weber, 2011; Weber and Tarba, 2011). 
The literature on cross-border M\&As can be segmented into the following strands: First and foremost, there is research interest in organizational amalgamation issues related to M\&A performance effects (e.g. Lien et al., 2006; Wang and Boateng, 2007; Zollo and Meier, 2008; Zou and Simpson, 2008). Secondly, issues involving human resources practices (e.g. Antila and Kakkonen, 2008; Marks and Mirvis, 2011b; Weber and Fried, 2011), employees' dismissal (e.g. Yong and Aguilera, 2008), due diligence (e.g. Angwin, 2001), and communication and management of soft-factors (e.g. Weber, Rachman-Moore, and Tarba, 2012). The third research avenue focuses on national cultural differences in international M\&As (e.g. Kroon, Noorderhaven, and Leufkens, 2008; Morosini, Shane, and Singh, 1998; Saunders, Altinay, and Riordan, 2009; Tanure et al., 2009).

This paper specifically reviews M\&A integration from the perspective of performance enhancement and success (Froesea and Goeritz, 2007; Haspeslagh and Jemison, 1991). However, rather than looking at cross-border M\&A in more general terms, we look specifically at departmental, functional integration (Ghauri and Buckley, 2003; Shimizu et al., 2004), in our case marketing integration. While a few select studies have already examined the role of functional/marketing integration (Homburg and Bucerius, 2005; Vanitha, Feisal, and John, 2008), given that the marketing department is seen as an important enabler of cross-border M\&A integration success our contribution to the literature is twofold. First, we propose a conceptual model on how to accommodate the marketing integration in M\&As by introducing social capital factors and resource basedview factors as antecedents. Second, we bridge previous empirical work with a view of functional marketing integration and outline potential implications for future empirical research in this area.

\section{Motivation}

Despite existing studies in the area of M\&A integration in general and functional integration in particular, there is still room for conceptual and empirical explorations (Capron and Hulland, 1999). The rationale for looking at marketing area integration is that marketing offers a high potential to create sales synergy and new business opportunities through combining various functions and value chain components of the acquired and acquiring firm (Wan and Yiu, 2009). Weber and Dholakia (2000) stressed that marketing consolidation is a strategically motivated step in boosting revenues through adding new product lines and expanding market research especially in foreign countries. By building on 
a research model proposed by Homburg and Bucerius (2005), the present study proposes antecedents that facilitate the marketing integration process leading to enhanced M\&A performance (See Figure 1). Social networking elements such as collaboration and interaction are introduced. Collaboration and interaction are dimensions, which have been used as major success factors in contributing to M\&A post acquisition management generally (Marmenout, 2011; Puranam, Singh, and Zollo, 2003), and marketing departmental integration in particular (Kahn and Mentzer, 1998). Social capital elements such as interaction, coordination, control and conflict resolution are essential in cultivating new characteristics and employee motivation in organizational integration, particularly in the marketing environment (Srivastava, Shervani, and Fahey, 1999). Furthermore, human relations and direct connectivity are fundamental in developing comprehensive integration in M\&As through R\&D transfer, intensive personal contacts and joint marketing projects between the merging companies (Anderson, Havila, and Salmi, 2001).

Another important contribution is through the utilization of marketing resources, i.e. marketing synergy and redeployment of marketing resources. Synergy is a main goal that firms aspire to accomplish (Larsson and Finkelstein, 1999). However, synergies in M\&As are not easy to achieve and represent a significant financial burden (Schweiger and Very, 2003; Sirower and Sahni, 2006). . Arguably, concentrating on the integration of marketing departments in M\&As is a lucrative strategic approach leading to synergistic benefits (Weber and Dholakia, 2000). The amalgamation of marketing departments offers tremendous advantages such as ready-made sales executives to boost sales revenues, opportunities to combine marketing functions such as logistics and sales operation as well as to slash advertising and promotion costs, and also the potential to reduce overlapping and surplus resources.

With regards to the redeployment of marketing resources, Capron and Hulland (1999) highlight that acquisitions offer an opportunity to capture new marketing resources such as brands and sales forces that are rather difficult to develop internally. Furthermore, through acquisitions the acquirer firm can redeploy its superior marketing resources in the target firm, which may push marketing efforts and contribute to improved revenue generation. In a similar vein, Anand and Singh (1997) state that if the firm can redeploy its resources or assets, then subsequent M\&A performance will be improved. Lakshman (2011) proposes a knowledge-resource based model to cultural integration in M\&As and explains the processes through which these resources impact integration effectiveness. This 
corresponds to findings by Ahammad and Glaister (2011) who assert that knowledge transfer to and from the acquired firm is significant positive determinant of acquisition performance.

However, applying M\&As as a strategy to integrate resources from two different organizations into one major entity may encounter a number of challenges, especially during the integration process at the functional level. After reviewing Weber and Dholakia's (2000) research about synergies in M\&As, Maruca (1996) states that firms in almost all the cases spent too much time focusing on financial outcomes and not enough on planning how to integrate the combined firms. Consequently, they failed to recognize the potential for synergies such as marketing advantages and economies of scale in terms of the partner's product lines, market position, existing customers and enthusiastic marketing personnel.

Additionally, it is a challenging task to combine two firms from different geographic areas and with different organizational cultures (King et al., 2004; Very and Lubatkin, 1996; Weber, Shenkar, and Raveh, 1996). According to Meschi and Metais (2006), one of the major challenges during the integration process in M\&As is the difficulty of developing and exploiting skills and acquiring knowledge. Aguilera and Dencker (2004) note that a lack of compelling strategic rationale and unrealistic expectations about possible synergies are also among the issues that undermine the process of integration. In fact, failing to implement favorable integration processes could lead to inferior acquisition outcomes (Cartwright and Schoenberg, 2006). However, a clear communication of the purpose of the integration together with careful planning and execution create a favorable environment for the achievement of synergies which then can contribute to M\&A success in terms of an enhanced financial performance.

Therefore, special arrangements are needed to facilitate the success of the integration process, particularly in the integration of marketing departments. Marketing managers can be seen as the most resourceful managers in enhancing profits and growth, especially by retaining existing customers and capturing new customers (Richey et al., 2008). As a foreign firm, the acquirer is vulnerable due to its limited knowledge of how to capture the local market in the acquired firm's country. Nevertheless, the acquiring firm can contribute in terms of its international experience and insights from its home country marketing strategy. Yet, all of these individual contributions are not sufficient without 
carefully planned and implemented procedures to enhance inter-firm collaboration and knowledge transfer.

\section{Theoretical background}

\subsection{Resource-based view (RBV)}

In M\&A research, the RBV has been discussed particularly in terms of the deployment and the integration of resources between target firms and acquirers (Capron, 1998; Colombo et al., 2007; Yung-Ming, 2006). It also provides the identification of a proactive strategy associated with strategic resources that are valuable, rare, imperfectly imitable and not substitutable within a firms' sustained competitive advantage (Barney, Wright, and Ketchen, 2001; Lockett, Thompson, and Morgenstern, 2009). This means that by engaging in M\&As firms can enhance their global competitiveness and obtain tangible or intangible resources. However, according to Harrison et al. (2001) the acquisition of resources is not sufficient for the creation of long-term competitive advantages. To sustain a competitive advantage the combined firm needs to be able to create a valuable, unique and inimitable synergy.

In this study, we look at how the RBV applies to the redeployment of marketing resources and to marketing synergy. These factors are used to expedite the process of marketing integration in order to achieve a better M\&A performance (Homburg and Bucerius, 2005). Redeployment of marketing resources is vital as it is key at the operational level in departmental amalgamation (Bahde, 2003). It requires strategies that allow both firms to exchange information and develop a strong marketing personnel (Harrison et al., 2001). This may help marketing managers to identify and communicate their strengths by highlighting successful and failed past and present strategies. The best marketing strategies can then be redeployed (Capron and Hulland, 1999).

In terms of marketing synergy, we base our arguments on those of Chatterjee (1986). He shows that a collusive synergy is associated with higher value compared to financial synergy and operational synergy. Collusive synergy is achieved by companies that exhibit similar industry or departmental background and are combined into one entity. In our study, this translates into the identification and realization of marketing resource synergies such as advertising, distribution, sales force and market research. These are important for the development of marketing capabilities and proficiencies in the newly-combined firm (Song, Montoya-Weiss, and Schmidt, 1997). Therefore, if both firms make an effort to combine 
their marketing capabilities to realize hidden synergies the newly combined firm is likely to be able to increase its performance through superior marketing activities (Larsson and Finkelstein, 1999).

\subsection{Social capital theory}

Social capital has emerged as one of the most salient concepts in the social sciences and is of central interest to organizational researchers (Adler and Kwon, 2002; Lin, Cook, and Burt, 2006). It refers to the extent to which members of an organization are driven to establish social contacts and interactions within or outside their organization ( $\mathrm{Li}$ and Chen, 2010). This concept looks at how social interactions such as public relations can facilitate mutually beneficial cooperation and coordination (Putnam, 1993) and how social capital can enhance network and industry growth (Walker, Bruce, and Weijian, 1997). Furthermore, issues such as the creation of inter-unit linkages through networks (Tsai, 2000), external knowledge acquisition through customer relationships (Yli-Renko, Autio, and Sapienza, 2001), the creation and sharing of new intellectual capital (Nahapiet and Ghoshal, 1998), knowledge transfer between network members (Inkpen and Tsang, 2005), and social capital as the driver of alliances (Chung, Singh, and Lee, 2000) are also key in social capital theory.

In this study, we highlight interaction and collaboration as the core social capital drivers enhancing marketers' relationships (Weiss and Hughes, 2005) and leading to a smooth interdepartmental integration, particularly when integrating the marketing department with other departments, such as manufacturing and research and development (R\&D) (Kahn and Mentzer, 1998). This is also emphasized by Duysters et al. (1999) with respect to establishing combination capabilities through business communities and the improvement of partner selection processes. Furthermore, these social capital drivers could develop into long-term relational advantages and at the same time expedite the marketing integration process. This is supported by Jean et al. (2010), who stress that social capital creates commitment among the partners. Increased commitment leads to resource sharing that is mutually beneficial to both parties. These relationships could also improve the likelihood of successful marketing integration within cross-border M\&As.

In M\&A integration, communication and cooperation among staff are vital (Sirower and Lipin, 2003). In fact, within M\&As almost all organizational restructurings that involve the integration of people require the application of soft side strategy through the relationship capital approach (Cullen, Johnson, and Sakano, 2000; Sudarsanam, 2003). 
According to Marks and Mirvis (2000), firms that are involved in M\&As will be able to integrate more smoothly if they develop some form of transition structure, which they can achieve through educating their staff and improving social interactions. Teerikangas, Satu and Pisano (2011) highlight the significance of 'integration managers' throughout the integration process, thus emphasizing the value-capturing roles of managers and their contribution to acquisition performance. This is in line with the notion that communication aspects and emotions are important contributors to M\&A integration (Kusstatscher, 2006). Hence, we introduce the aspect of social capital as antecedents to the marketing integration process, (see Figure 1). It links through the interaction and collaboration based on a study conducted by Kahn and Mentzer (1998). Thus, the RBV and the social capital theory are applied to explain how resources such as interaction, collaboration, marketing synergy and redeployment of marketing resources are used and manipulated to expedite the process of marketing integration and ultimately to achieve better M\&A performance.

\section{Insert Figure 1 here}

\section{Previous research - marketing integration process in M\&As}

Marketing integration is not only concerned with internal collaboration within an organization but also with collaboration across firms. This collaboration is much more complex if it involves two different countries, especially in the case of a firm from a developing country acquiring a firm in a developed country. Although the overall aspect of the integration process will be similar, factors such as different cultures and unexpected local behavior could jeopardize the integration. This process becomes more complicated in the M\&A context. Therefore, the integration process must be effectively managed in order to avoid failures and at the same time improve the M\&A performance.

As there is no uniform definition of the marketing integration process (Rouzies et al., 2005), we define it as the combination of two marketing departments into one major entity which will coordinate and manage large marketing resources. The term process does not refer to a stepwise method but rather to proposed mechanisms that can expedite and provide benefits for the combination of the two marketing departments. Figure 1, shows the proposed conceptual model for the marketing integration process in the M\&A context.

Research into marketing integration began with the discussion of behavioral factors For example, Ruekert and Walker (1987) examine how the marketing staff interacts with 
staff in other functional areas in terms of fulfilling marketing functions. They introduce an inter-functional interactions framework divided into three main dimensions; 1) environmental situation, 2) structure and process and 3) outcome dimensions of an interfunctional social system. The findings indicate that inter-functional interaction involving marketing personnel and other personnel is influenced by resource dependencies. Secondly, co-ordinations seem to play an important role in linking cross functional units. Furthermore, it appears that the more similar two functional departments are in tasks and objectives, the greater the amount of communication that will occur between the individuals in two departments and also the less difficulty they will encounter in communicating effectively with one another. Finally, the degree of conflict seems to increase if the level of interaction increases between marketing personnel and another functional area.

Kahn and Mentzer (1998) propose that among the behavioral elements that are related to social factors, interaction and collaboration are the major drivers in influencing performance outcomes within the marketing integration area. They emphasize that meetings and information flows between departments lead to better interactions (Nick, 2008). Furthermore, collaboration is found to act as an affective sharing process which develops commitments that are required to achieve togetherness. Accordingly, the collaboration component should be emphasized to achieve better performance in integrating two departments. On the other hand, interaction should be employed as a bridge to establish contacts. Too many meetings and documented information exchange may jeopardize performance as too much interaction can lead to unfavorable relationships.

Other research streams focus on the integration of marketing departments with other departments such as R\&D (Parry and Song, 1993), sales (Guenzi and Troilo, 2006; Palmatier, Miao, and Fang, 2007), human resources (Chimhanzi, 2004), quality (Longbottom, Mayer, and Casey, 2000), logistics (Ellinger, 2000), the Internet (Prasad, Ramamurthy, and Naidu, 2001; Uhlenbruck, Hitt, and Semadeni, 2006) manufacturing (Song, Montoya-Weiss, and Schmidt, 1997), engineering (Lancaster, 1993) and other departments.

In terms of R\&D and marketing department integration, Griffin and Hauser (1996) stress the importance of joint product development and innovativeness. The high level of cooperation and the amalgamation of expertise results in more marketable products, improves sales and reduces product failures in the marketplace (Garrett, Buisson, and Yap, 2006). Another outcome of $R \& D$ and marketing integration can be improved new idea 
generation and product commercialization (Song, Montoya-Weiss, and Schmidt, 1997). Song et al. (1997) examine whether other departments for example the manufacturing department could also play a major role in the integration process. Manufacturing departments can contribute in terms of increased production efficiency and cost minimization (Goodman and Dion, 2001). Through this, the combined firm gains advantages which supports the R\&D and marketing department. Song et al. (1997) introduce two antecedents: internal facilitators and external forces. They find that internal facilitators such as evaluation, reward procedures, and top management support significantly influence cross-functional cooperation and new product performance.

Cho and Hahn (2004), on the other hand, examine the antecedents and consequences of the sociocultural differences between $\mathrm{R} \& \mathrm{D}$ and marketing managers. They emphasize the importance of a joint reward system and interdepartmental connectedness. However, their results show that sociocultural differences are barriers to the inter-functional integration between $\mathrm{R} \& \mathrm{D}$ and marketing departments and thus, do not support better NPD performance. Khan (2001) investigates the influence of market orientation and interdepartmental integration on NPD performance in relation to the marketing and manufacturing departments. The findings confirm that market orientation and interdepartmental integration significantly improve product development and product management performance.

In terms of integration between marketing and sales departments, Rouzies et al.(2005) propose integrating mechanisms as the antecedents of sales and marketing integration such as structure, process/system, culture and people. Guenzi and Troilo (2007), on the other hand, suggest long-term strategic orientation, an effective marketing-sales relationship and customer-oriented sales people as antecedents. Surprisingly, research into marketing department integration particularly within the M\&A context is limited (Homburg and Bucerius, 2005).

Capron and Hulland (1999) study the redeployment of three marketing resources (brands, sales forces and general marketing expertise), specifically in merging firms following horizontal acquisitions. They investigate the impact of such redeployments on performance. According to their findings, all three marketing resources are likely to be redeployed evenly in the M\&A contexts. They report that the immobile resources are more likely to be redeployed from the acquired firm compared to the otherwise less immobile resources. Furthermore, resources are more likely to be redeployed from acquirer to 
acquired rather than in the reverse direction. Ultimately, all the three marketing resources are reported to positively affect the firm's performance.

Another interesting study on marketing integration within the M\&A context is by Homburg and Bucerius (2005). The study investigates firms operating in the Germanspeaking part of Central Europe (Germany, Austria and Switzerland). . The results indicate that marketing integration contributes to cost savings but has a negative effect on marketrelated performance.

Vanitha et al. (2008), on the other hand, investigate how marketing functions create value in M\&A. They examine when and how similarity and complementarity between merging firms create value but under varying merger motives. They attempt to address any linkages that may exist between marketing resources and financial performance. They find that marketing actions such as consolidating products and markets can produce positive impact on shareholder value.

Weber et al. (2011) explore the fit of the integration approach to the synergy potential of the merged companies and the cultural differences between them. The results indicate that there is a positive relationship between the fit of the integration approach and integration effectiveness. Furthermore, this relationship is mediated by the synergy potential and cultural differences.

Despite the fact that studies specifically investigating marketing integration in M\&As are rare, studies focusing on M\&A integration have made valuable contributions to topics such as strategic fit (Datta, 1991), synergy realization (Larsson and Finkelstein, 1999), relationship marketing (Richey et al., 2008), integration between biotechnology and pharmaceutical companies (Schweizer, 2005), organizational integrity (Cording, Christmann, and King, 2008) and learning (Zollo and Singh, 2004). Please refer to Table 1.

Insert Table 1 here

\section{Antecedents to marketing integration in the M\&A context}

Within this body of literature, to the best of our knowledge, no previous studies have proposed antecedents to the marketing integration process which are simultaneously expected to improve M\&A performance. Although some researchers have explored the area, their studies had a different and unrelated context. For example Song et al. (1997) explore 
the antecedents of cross-functional cooperation in the integration of marketing, $R \& D$ and manufacturing departments in the Mexican electronic industry. Others have investigated the topic in the context of socio-cultural differences between the integration of $R \& D$ and marketing departments in the Korean high-tech industry (e.g. Cho and Hahn, 2004). Bahde (2003) discusses M\&A integration in general rather than going deeper into an operational setting. Hence, in the present study, following Homburg and Bucerius (2005) and Capron and Hulland (1999), we propose four antecedents for the marketing integration process. These antecedents are collaboration, interaction, marketing synergy and redeployment of marketing resources. These antecedents are clearly shown in Figure 1.

\subsection{Collaboration}

Combining people in M\&A integration is a challenge as it involves various backgrounds and different needs which can represent enormous obstacles during the integration process. These obstacles include differences in work setting, company goals and vision, business applications and mindset. However, collaboration among staff is critical to business success, especially when it involves combining two entities into one. This is more difficult when integrating two different national backgrounds into one. One way to facilitate the integration process is by fostering understanding among staff members through formal and informal social network collaboration (Birkinshaw, Bresman, and Hakanson, 2000).

Kahn and Mentzer (1998) find that formal collaboration such as working together, achieving goals collectively and sharing ideas are among the most popular collaboration approaches employed to facilitate the integration of marketing and manufacturing departments. In terms of informal collaboration approaches, working together informally was found to significantly influence the integration process. Blomqvist and Levy (2006) underline that collaboration is a key to enable knowledge creation in an uncertain environment. Drawing on the organizational trust literature and research on post-merger integration, Stahl et al. (2011) propose that the two firms' relationship history, the inter-firm distance, and the acquirer's integration approach will influence target firm employees' trust in the acquiring firm's management (Stahl et al., 2011). Furthermore, collaboration with foreign partners can benefit firms through providing them with knowledge and strategies that might be extremely costly and difficult to obtain via other methods of cross border entry, such as joint ventures and other non-equity alliances (Shrader, 2001). 
Another approach is to encourage staff collaboration on joint projects. Teamwork and collaboration enable the sharing of resources through interdepartmental connections (Weiss and Hughes, 2005). At the same time, it fosters marketing know-how and skills exchange. Similarly, Stank et al. (1999) find that the more frequently collaborative projects take place, the better the subsequent performance and the easier the implementation of improvements in interdepartmental relationships. Therefore we propose:

\section{P1: The greater the marketers' collaboration, the better the extent and speed of marketing integration}

\subsection{Interaction}

In general, the term interaction refers to any contact or relationship that is directly implemented, be it with customers, staff, or employees under a particular manager's supervision or outside his supervision. In particular, interaction concerns communication activities during a specific project or assignment collaboration. In our context, interactions among staff are mostly related to the process of disseminating information through communication, cooperation and conflict resolution within a complex international assignment such as international joint venture (IJV) and other strategic alliances (Damanpour et al., 2010). From a marketing perspective, interactions take place in the marketing environment and concern the relationship between a marketing manager and his subordinates. It refers to how the marketing manager carries out his coordinating role in terms of achieving customer satisfaction (Ruekert and Walker Jr, 1987).

In M\&As, these transaction and communication activities are mostly applied during the integration process to encourage information sharing, increase trust and staff coordination and most importantly to avoid potential conflicts between the two firms. The aim is not only to develop a smooth information flow but also to foster a sense of common identity and commitment by enforcing active interaction among them. In fact, most of the interactions come from information exchange including meetings, teleconferencing, memoranda and the exchange of any standard documentation (Kahn and Mentzer, 1998). Furthermore, communication in M\&As has been identified as a vital driver in routine working environments but little explicit attention has been given to the question of staff interaction between acquiring and target firm (Allatta and Singh, 2011).

Kahn and Mentzer (1998) study interactions in the integration of marketing departments with other departments such as R\&D and manufacturing. In our work, we look at marketing integration in M\&As. We define interaction as a method of communication 
such as by telephone and by email that facilitates relationship building between the two marketing departments. This is important as communication will be a basic road map to guide those marketers when making decisions during the transition process (Schweiger, 2002). Therefore, this leads to the research proposition below.

\section{P2: $\quad$ The greater the level of interaction, the greater the extent and speed of integration}

\subsection{Marketing synergy}

We use the definition of Weber and Dholakia (2000) to define marketing synergy, that is the combination of the two firms by reducing duplicated marketing-related resources. However, this synergy must be effectively managed especially during the period of integration otherwise the combining entity may suffer losses. If it is managed appropriately, marketing synergy can lead to the creation of a competitive advantage and to enhanced firm performance (Hooley et al., 2005). For example, Harrison et al. (1991) show that when firms acquire other firms which are in some form related to them, this will create synergy. This is also supported by Nils Bohlin (1998) who states that the synergy created during M\&As can develop dynamic energy arising from ongoing encounters between people and groups with different world views, knowledge, and experience, and it transforms the whole idea into something greater than the sum of its parts. Weber, Tarba and Reichel (2011) develop a theoretical model and explore the combined effects of corporate culture, national culture, and synergy potential on various integration approaches as well as their influence on M\&A performance by combining variables of pre- and post-merger stages.

To harness the valuable differences between two merging companies and convert them into opportunities for innovation, performance excellence, and market leadership, the combined companies need to take a very careful look at the entire integration process. One notable study in synergy was conducted by Larsson and Finkelstein (1999). In fact, their study leads us to propose marketing synergy as a factor. They examine how synergy realization is a function of the similarity and complementarities of the two merging businesses (combination potential). The challenge of this situation starts with how to integrate and manage similar marketing resources and then to avoid the overlapping of operations incurring unnecessary costs. Therefore, they need to identify duplicate resources such as advertising strategies, sales force skills and others (Larsson and Finkelstein, 1999).

The present study proposes that marketing synergy is one of the factors contributing to the efficiency of the marketing integration process. This synergy is believed to lead to a 
better combination of products or services important for obtaining new customers and also key to customer retention (Richey et al., 2008). It can also reduce other potential duplications such as warehousing, brand positions, customer service facilities, advertising, product development efforts etc. (Hakkinen, 2005). Thus, the marketers of both firms need to determine to what extent they should be integrated so that the resulting marketing synergy enhances the effectiveness of the new marketing strategy in both firms. The first challenge is how to integrate and the next is how to avoid overlaps in their operations, which would incur unnecessary costs. Therefore, we propose:

\section{P3: The greater the degree of marketing synergy, the greater the extent and speed of integration}

\subsection{Redeployment of marketing resources}

The redeployment of marketing resources promotes the sharing and structuring of marketing resources of both the acquiring and the acquired firm. Guenzi and Troilo (2007) note that this strategy enhances marketing capabilities by generating superior customer service. However, more attention needs to be accorded to the collaborative relationships among marketers as these are the key to developing a smooth structuring process and synchronization within the marketing integration. In this study we define the redeployment of marketing resources as the use of partner resources by the other partner, which may involve a physical transfer of resources to a new location or the sharing of marketing resources without physical transfer.

Krishnan et al. (2004) study the redeployment of resources in M\&As leading to product-mix reconfiguration toward high-profit products. They show that resource redeployment can translate into product portfolio enhancement or market share increase. They also stress that mergers facilitate the product-mix reconfiguration by relaxing institutional and organizational constraints on resource redeployment. By looking at the hospital industry in the US, they find that resource redeployment towards attractive product lines does not appear to eliminate the unprofitable product lines. This is due to the nonprofit status of most of the hospitals in thesample.

Anand and Singh (1997) emphasize that some resources are fungible, Firms with declining existing businesses should be able to redeploy some of their resources when they enter new markets. This can be done by redeploying the resources within the firm through diversification-oriented acquisitions or through consolidation-oriented acquisitions. Anand and Singh's (1997) results indicate that consolidation is a better choice for firms in 
declining industries compared to diversification if they are seeking a higher return. This is mostly due to the costs and risks involved in the transformation of a firm. Since it is more profitable to redeploy resources in a consolidation environment, firms should measure the attractiveness of potential targets by identifying opportunities for consolidation.

M\&As can be also used as an alternative way of capturing new resources, specifically marketing resources such as unique and established brands that most firms find difficult to develop internally within a short period of time (Jaju, Joiner, and Reddy, 2006). In fact, combining brands or using a new brand, especially to market a particular product or service is a key factor in speeding up integration (Hise, 1991). Capron and Hulland (1999) also note that the redeployment of marketing resources such as brands, sales force and general marketing expertise can enhance the acquiring company's competitive position and lead to better financial performance, especially if the organic development of these resources is difficult or time-consuming.

Based on the above arguments, we propose that:

P4: The greater the redeployment of marketing resources, the greater the extent and speed of integration

\section{Marketing integration}

\subsection{Extent of integration}

Since an integration can cause costly and time-consuming changes, Schweiger (2002) posits that only those functions, lines of business and geographic areas that support the strategy and source of synergy should be integrated. Simlarly, Datta (1991) stresses that the main benefit of integration is to make more effective use of the existing resources and capabilities. In addition, the integration of duplicate departments and functions reduces costs in production, finance, inventory holding, marketing, advertising and distribution (Howell, 1970). For this reason, this stage is also known as the transition stage, during which the acquirer examines each area of business and decides what and to what extent to integrate (Schweiger, Ivancevich, and Power, 1987). If integration plans can be developed early in the process, such as during the transition period, organizations can make important changes quickly. The quicker they confirm which areas they will combine, the better the integration process will be.

According to Homburg and Bucerius (2005), M\&A integration can be either low or high in their extent of integration. However, a low or high level of integration does not 
necessarily lead to high or low cost savings. In other words, a deep integration is not always the best solution. A further benefit of integration is its potential impact on staff relationship enhancement (Schweiger and Goulet, 2000). These relationships are key in terms of knowledge and information sharing (Zhanwen and Haifeng, 2007). A lack of information sharing between the two firms could jeopardize the future success of the integrated entity.

We use a similar dimension to that proposed by Homburg and Bucerius (2005). The merits of both firms are evaluated in terms of marketing systems, structures, activities and processes. Furthermore, the extent to which the two firms are different in terms of sales systems also needs to be weighed in order to determine how they can be integrated. Therefore, we propose:

\section{P5: The greater the extent of integration, the greater the M\&A performance}

\subsection{Speed of integration}

Speed in M\&A integration is associated with decisiveness, gaining advantages and time saving (Angwin, 2004). Speed is found to be particularly important in the integration process (Homburg and Bucerius, 2006; Orit, Charles, and Sam, 2003). It is defined as the period of time needed to achieve the intended level of marketing integration (Homburg and Bucerius, 2006). A slow integration process is suggested to create problems and weakens the opportunity to take advantage of the energy stirred up by an M\&A (Huang and Kleiner, 2004). Practitioners and consultants are increasingly praising the virtues of acting rapidly post-deal and the first 100 days are claimed to be critical for acquisition success (Angwin, 2004). According to Schweiger and Goulet (2000), the issue of speed can be categorized into two schools of thought: the slow integration approach and the idea that integration should be executed as quickly as possible.

In the first approach, the acquirer takes time to get to know the target firms, staff, culture, operations and markets before making any drastic changes. Some empirical evidence suggests that uncritical acceptance of the benefits of speed in post-acquisition integration may prove detrimental to performance (Angwin, 2004). The alternative is to pursue a speedy integration. This approach suggests that transformations to make the new business work efficiently should be done swiftly and that fast integration motivates employees to stay on during the transitional stages (Schweizer and Patzelt, 2012). Schweizer and Patzelt (2012), find that fast integration has a positive effect on employees' motivation to stay with the firm. They also find that the more the leadership style of their 
supervisors is characterized as relational, contextual, inspirational and supportive, the stronger the positive effect of fast integration is. Hadjian (2000) uses a metaphor to suggest that the speed of integration is actually a "hinge" that holds together the success of the combined firm. We thus propose that:

P6: $\quad$ The greater the speed of the integration, the greater the M\&A performance.

\section{Conclusion and future directions}

This paper set out to make a contribution through extending our understanding of the marketing integration process in cross-border M\&As as first mentioned and explored by Homburg and Bucerius (2005). In doing so, the antecedent dimensions collaboration, interaction, marketing synergy and redeployment of marketing resources were introduced in order to support the marketing integration process in cross-border M\&As. The integration stage of cross-border M\&As is crucial, as it determines whether the combination of the companies will improve the organization's sustainability and growth particularly at the international level. This may even be a matter of survival, as many M\&As have not prevailed due to half-hearted attempts at the integration stage (Cartwright and Schoenberg, 2006). In fact, many M\&A studies have emphasized that the integration stage is the key to harmonizing and educating which are the key for making the integration successful (Bower, 2001; Buckley and Ghauri, 2002; Cartwright and Cooper, 1990).

Therefore, this paper attempts to expand the current understanding of the marketing integration process in the M\&A context by developing a conceptual model and incorporating and conceptually supporting antecedent factors. We argue that these antecedent factors can facilitate the marketing integration process in cross-border M\&As. We argue that the interaction and collaboration among marketers who are involved in the M\&A will revitalize the structure and strategies of previous marketing departments (Weber and Dholakia, 2000). These activities can enhance the new marketing environment which emerges in the new combined firm thereby boosting the M\&A performance. In previous studies, these factors have been revealed to support marketing integration (Stank, Daugherty, and Ellinger, 1999). Additionally, we also propose marketing synergy and the redeployment of marketing resources (Weber, Tarba, and Bachar, 2011). We believe that the integration of two firms through an M\&A may create synergy, economies of scale, value and the bundling of resources both for the firms and the shareholders (Almor, Tarba, and Benjamini, 2009; Hitt, 2001; Wang and Zajac, 2007). However, these resources need to 
be wisely managed and streamlined in order for the newly combined firm to integrate effectively.

We also highlight some future research avenues derived from these propositions. Future research may wish to look at specific industries providing more in-depth findings and a better understanding of certain business phenomena. Such research would ultimately lead to improved business strategies and allow us to learn from previous lessons as has been done, for example, in the banking industry (Kim and Finkelstein, 2009). Cross-country comparisons may also lead to interesting and highly valuable results in future studies. For example, the study conducted by Harris and Carr (2008), revealed that national values influence business directions and explain management behavior which signals the true behavior of international managers. Therefore, an in-depth study is needed to unveil this phenomenon, particularly in the context of cross-border M\&As (Meglio and Risberg, 2011).

Furthermore, the scope of the marketing integration process in M\&As is limited to the marketing environment which cannot be generalized to other departments such as manufacturing, logistics, human resources or R\&D. This investigation is focused on how the marketing departments of two firms can be combined to improve and to utilize the marketing resources from two different countries. Consequently, future research may wish to investigate the integration process in other departments.

The present study only focuses on collaboration, interaction, marketing synergy and redeployment of marketing resources. However, there are many other potential factors that could be employed as antecedents of the success of the marketing integration process. Future studies could also explore other antecedent elements, especially in terms of human factors related to the marketers involved in the M\&A integration. In fact, previous research findings indicate that the interaction of human factors is vital to the success of M\&A integrations (Vasilaki, 2011; Weber and Tarba, 2010). For instance, in the integration of the marketing and sales departments, Rouzies et al. (2005) propose integrating mechanisms that encompass organizational structure, process, culture and people. On the other hand, Garrett et al. (2006) proposes four mechanisms: formalization, centralization, role flexibility and inter-functional climate which boost the integration of a marketing department with a $R \& D$ department, which eventually improving new product development.

Another avenue for future studies may be the focus on issues around branding. How does the combined firm utilize its brand or integrate its brand in order to enhance the 
marketing strategy within the M\&A context? This is an interesting issue with high potential for future research (Cem, Bharadwaj, and Srivastava, 2008; Dieng, Dörrenbächer, and Gammelgaard, 2009; Lambkin and Muzellec, 2008).

Another recent issue that possibly influences departmental integration is staff emotions. Nowadays, emotion in the workplace is a popular topic in organizations (Callahan, 2008). A study would likely entail how and whether the integration process in an M\&A would affect the marketers' emotions, what kind of emotions influence the integration and most importantly, whether emotions could improve or worsen motivation in the integration process and how emotions could be countered. According to Callahan (2008), these emotions can be countered through emotional intelligence, the ability to recognize and manage our own and others' emotions through four clusters: context, challenges, communication and community. In fact, emotional intelligence has been stressed in a different way in relation to the attachment experience within acquisitions (Schweiger, Ivancevich, and Power, 1987). Hence, emotional intelligence can be used to construct a fit measure to evaluate the impact of the antecedents of the marketing integration process within the M\&A contexts. Furthermore, Finkelstein et al. (2009) emphasize the powerful emotions involved in making considerable decisions, particularly concerning the issues of integrating two firms into one new entity. A recent example in this area is a paper by Sinkovics et al. (2011) who explore how managers behave and communicate by drawing on employees' emotional perceptions.

Further research could also extend the marketing integration process not only to focus on the speed and extent of the marketing integration process, but also to examine aspects such as the visibility of the organizational structure while the two firms combine, the degree of coordination through communication flow in the integration process and the flexibility of the departments of the acquirer and the target firm in acknowledging the integration procedure. Another notable issue about the integration phase is when the best time for two firms to combine is and how unhappy subordinates should be managed during the integration process. As for the marketing integration outcomes, the present study uses cost savings and relationship effectiveness among the marketers. It is recommended that a further in-depth investigation of each of the marketing integration outcomes should be undertaken. For example, to what extent do the marketers get together to resolve any problems and improve relationships after they have been involved in the integration process. 
Experience in M\&As has been widely used as a control variable and some previous studies have even used it as a moderator, however past research has given mixed results and therefore it is unlikely to reveal an energizing of firm acquisition performance (Meschi and Metais, 2006). Some international firms such as General Electric Capital (GE) have been successful in using their experience in M\&As as a business development tool. In fact, half of its businesses were generated through acquisitions and it is believed to employ the M\&A as a replicable process rather than a one-time only event (Ashkenas, DeMonaco, and Francis, 1998). Hence, M\&A experience can be proposed for future studies particularly to be the control variable and maybe as moderator.

Finally, the M\&A performance measures in our study were all perceptual described in terms of general performance such as the level of customer servicel, return on investment etc. Further research may wish to explore two levels of dependent variables: financial performance and non-financial performance. Instead of focusing solely on M\&A performance, future studies could look at financial performance, for example acquirer performance (Laamanen and Keil, 2008), operating performance (Cornett, McNutt, and Tehranian, 2006) and financial performance: accounting returns and investor returns (Fowler and Schmidt, 1988). On the other hand, in terms of non-financial performance, we would suggest that future studies look at the marketing performance in the M\&A context. Marketing performance will provide more insights into the marketing discipline. Moreover, as this study marketing integration, by employing marketing performance, future studies would be able to identify specific marketing aspects that prevail in the M\&A context. Further details about marketing performance can be explored through articles by Ambler and Roberts (2008) and Craig and Aron (2002).

In all, the marketing integration process is a critical agenda to marketing department, particularly in organizing marketing resources in cross-border M\&As as it can be expected to lead to better outcomes through superior marketing combination and the bundling of marketing resources. The challenge of integration needs to be supported by using appropriate antecedent factors such as collaboration, interaction, marketing synergy and redeployment of marketing resources to ensure its effectiveness and to avoid conflict among marketing staff. Additionally, the relationship between the two parties needs to be positively managed as communication and cooperation are crucial drivers of M\&A strategy success (Kusstatscher, 2005; Weber et al., 2012). 


\section{References}

Adler, P.S. and Kwon, S.-W. (2002) 'Social capital: Prospects for a new concept', Academy of Management Review, Vol. 27, No. 1, pp. 17-40.

Agrawal, A., Ferrer, C., and West, A. (2011) 'When big acquisitions pay off', McKinsey Quarterly, No. 3, pp. 103-08.

Aguilera, R.V. and Dencker, J.C. (2004) 'The role of human resource management in crossborder mergers and acquisitions ', International Journal of Human Resource Management, Vol. 15, No. 8, pp. 1355-70.

Ahammad, M.F. and Glaister, K.W. (2011) 'Postacquisition management and performance of cross-border acquisitions', International Studies of Management \& Organization, Vol. 41, No. 3, pp. 59-75.

Allatta, J.T. and Singh, H. (2011) 'Evolving communication patterns in response to an acquisition event', Strategic Management Journal, Vol. 32, No. 10, pp. 1099-118.

Almor, T., Tarba, S.Y., and Benjamini, H. (2009) 'Unmasking integration challenges: The case of biogal's acquisition by teva pharmaceutical industries', International Studies of Management and Organization, Vol. 39, No. 3, pp. 32-52.

Ambler, T. and Roberts, J.H. (2008) 'Assessing marketing performance: Don't settle for a silver metric', Journal of Marketing Management, Vol. 24, No. 7/8, pp. 733-50.

Anand, J. and Singh, H. (1997) 'Asset redeployment, acquisitions and corporate strategy in declining industries', Strategic Management Journal, Vol. 18, No. S1, pp. 99-118.

Anderson, H., Havila, V., and Salmi, A. (2001) 'Can you buy a business relationship? On the importance of customer and supplier relationships in acquisitions', Industrial Marketing Management, Vol. 30, No. 7, pp. 575-86.

Angwin, D. (2001) 'Mergers and acquisitions across European borders: National perspectives on preacquisition due diligence and the use of professional advisors', Journal of World Business, Vol. 36, No. 1, pp. 32-58.

Angwin, D. (2004) 'Speed in M\&A integration: The first 100 days', European Management Journal, Vol. 22, No. 4, pp. 418-30.

Antila, E.M. and Kakkonen, A. (2008) 'Factors affecting the role of HR managers in international mergers and acquisitions a multiple case study', Personnel Review, Vol. 37, No. 3, pp. 280-99.

Ashkenas, R.N., DeMonaco, L.J., and Francis, S.C. (1998) 'Making the deal real: How GE capital integrates acquisitions', Harvard Business Review, Vol. 76, No. 1, pp. 16578.

Bahde, K.P. (2003) 'Riding the whitewater: A social constructionist approach to the mergers and acquisitions integration process and the role of the integration manager', Ph.D., Benedictine University, United States -- Illinois.

Barney, J., Wright, M., and Ketchen, D.J. (2001) 'The resource-based view of the firm: Ten years after 1991', Journal of Management, Vol. 27, No. 6, pp. 625-41.

Birkinshaw, J., Bresman, H., and Hakanson, L. (2000) 'Managing the post-acquisition integration process: How the human integration and task integration processes interact to foster value creation ', Journal of Management Studies, Vol. 37, No. 3, pp. 395-425.

Blomqvist, K. and Levy, J. (2006) 'Collaboration capability - a focal concept in knowledge creation and collaborative innovation in networks', International Journal Management Concepts and Philosophy, Vol. 2, No. 1, pp. 31-48.

Bower, J.L. (2001) 'Not all M\&A are alike-and that matters', Harvard Business Review, Vol. 79, No. 3, pp. 93-101. 
Buckley, P.J. and Ghauri, P.N. (2002) International mergers \& acquisitions: A reader, International Thomson Business Press, London.

Callahan, J.L. (2008) 'The four c's of emotion: A framework for managing emotions in organizations', Organization Development Journal, Vol. 26, No. 2, pp. 33-38.

Capron, L., Dussauge, Pierre and Mitchell, Will (1998) 'Resource redeployment following horizontal acquisitions in Europe and North America, 1988-1992', Strategic Management Journal, Vol. 19, No. 7, pp. 631-61.

Capron, L. and Hulland, J. (1999) 'Redeployment of brands, sales forces, and general marketing management expertise following horizontal acquisitions: A resourcebased view', Journal of Marketing, Vol. 63, No. 2, pp. 41-54.

Cartwright, S. and Cooper, C.L. (1990) 'The impact of mergers and acquisitions on people at work: Existing research and issues', British Journal of Management, Vol. 1, No. 2, pp. 65-76.

Cartwright, S. and Schoenberg, R. (2006) 'Thirty years of mergers and acquisitions research: Recent advances and future opportunities', British Journal of Management, Vol. 17, No. S1, pp. 1-5.

Cem, B.S., Bharadwaj, S.G., and Srivastava, R.K. (2008) 'Financial value of brands in mergers and acquisitions: Is value in the eye of the beholder?', Journal of Marketing, Vol. 72, pp. 49-64.

Chatterjee, S. (1986) 'Types of synergy and economic value: The impact of acquisitions on merging and rival firms', Strategic Management Journal, Vol. 7, No. 2, pp. 119-39.

Chimhanzi, J. (2004) 'The impact of integration mechanisms on marketing/HR dynamics', Journal of Marketing Management, Vol. 20, No. 7/8, pp. 713-40.

Cho, E. and Hahn, M. (2004) 'Antecedents and consequences of the sociocultural differences between R\&D and marketing in Korean high-tech firms', International Journal of Technology Management, Vol. 28, No. 7/8, pp. 801-19.

Chung, S.A., Singh, H., and Lee, K. (2000) 'Complementarity, status similarity and social capital as drivers of alliance formation', Strategic Management Journal, Vol. 21, No. 1, pp. 1-22.

Colombo, G., Conca, V., Buongiorno, M., and Gnan, L. (2007) 'Integrating cross-border acquisition: A process-oriented approach', Long Range Planning, Vol. 40, No. 2, pp. 202-22.

Cording, M., Christmann, P., and King, D.R. (2008) 'Reducing causal ambiguity in acquisition integration: Intermediate goals as mediators of integration decisions and acquisition performance ', Academy of Management Journal, Vol. 51, No. 4, pp. 744-67.

Cornett, M.M., McNutt, J.J., and Tehranian, H. (2006) 'Performance changes around bank mergers: Revenue enhancements versus cost reductions', Journal of Money, Credit \& Banking, Vol. 38, No. 4, pp. 1013-50.

Craig, J. and Aron, O.C. (2002) 'The effect of firm and marketplace characteristics on international joint venture (ijv) marketing performance', Asia Pacific Journal of Marketing and Logistics, Vol. 14, No. 1, pp. 19-39.

Cullen, J.B., Johnson, J.L., and Sakano, T. (2000) 'Success through commitment and trust: The soft side of strategic alliance management', Journal of World Business, Vol. 35, No. 3, pp. 223-40.

Damanpour, F., Devece, C., Chen, C., and Pothukuchi, V. (2010) 'Organizational culture and partner interaction in the management of international joint ventures in India', Asia Pacific Journal of Management, Vol. online first (DOI: 10.1007/s10490-0109204-x). 
Datta, D.K. (1991) 'Organizational fit and acquisition performance: Effects of postacquisition integration', Strategic Management Journal, Vol. 12, No. 4, pp. 281-97.

Dieng, S., Dörrenbächer, C., and Gammelgaard, J. (2009) 'Subsidiary brands as a resource and the redistribution of decision-making authority following acquisitions', in Finkelstein, S. and Cooper, C.L. (Eds.), Advances in mergers \& acquisitions Vol. 8, Emerald Group Publishing Limited, Bingley, pp. 141-60.

Duysters, G., Kok, G., and Vaandrager, M. (1999) 'Crafting successful strategic technology partnerships', $R \& D$ Management, Vol. 29, No. 4, pp. 343-51.

Ellinger, A.E. (2000) 'Improving marketing/logistics cross-functional collaboration in the supply chain', Industrial Marketing Management, Vol. 29, No. 1, pp. 85-96.

Finkelstein, S., Whitehead, J., and Campbell, A. (2009) 'How emotional tagging can push leaders to make bad decisions ', Ivey Business Journal, Vol. 73, No. 1, pp. 4-4.

Fowler, K.L. and Schmidt, D.R. (1988) 'Tender offers, acquisition and subsequent performance in manufacturing firms', Academy of Management Journal, Vol. 31, No. 4, pp. 962-74.

Froesea, F.J. and Goeritz, L.E. (2007) 'Integration management of western acquisitions in Japan', Asian Business \& Management, Vol. 6, pp. 95-114.

Garrett, T.C., Buisson, D.H., and Yap, C.M. (2006) 'National culture and R\&D and marketing integration mechanisms in new product development: A cross-cultural study between Singapore and new zealand', Industrial Marketing Management, Vol. 35, No. 3, pp. 293-307.

Ghauri, P.N. and Buckley, P.J. (2003) 'International mergers and acquisitions: Past, present and future', in Finkelstein, S. and Cooper, C. (Eds.), Advances in mergers and acquisitions Vol. 2, Emerald Group Publishing Ltd, Bingley, pp. 207-29.

Goodman, L.E. and Dion, P.A. (2001) 'The determinants of commitment in the distributormanufacturer relationship', Industrial Marketing Management, Vol. 30, No. 3, pp. 287-300.

Griffin, A. and Hauser, J.R. (1996) 'Integrating R\&D and marketing: A review and analysis of the literature', Journal of Product Innovation Management, Vol. 13, No. 3, pp. 191-215.

Guenzi, P. and Troilo, G. (2006) 'Developing marketing capabilities for customer value creation through marketing and sales integration', Industrial Marketing Management, Vol. 35, No. 8, pp. 974-88.

Guenzi, P. and Troilo, G. (2007) 'The joint contribution of marketing and sales to the creation of superior customer value', Journal of Business Research, Vol. 60, No. 2, pp. 98-107.

Hadjian, A.L. (2000) 'Speed: What it takes to make mergers work', Investment Dealers' Digest, Vol. 66, No. 31, pp. 11.

Hakkinen, L. (2005) 'Impacts of international mergers and acquisitions on the logistics operations of manufacturing companies', International Journal of Technology Management, Vol. 29, No. 3/4, pp. 362-85.

Harris, S. and Carr, C. (2008) 'National cultural values and the purpose of business', International Business Review, Vol. 17, No. 1, pp. 103-17.

Harrison, J.S., Hitt, M.A., Hoskisson, R.E., and Ireland, R.D. (1991) 'Synergies and postacquisition performance: Differences versus similarities in resource allocations', Journal of Management, Vol. 17, No. 1, pp. 173-90.

Harrison, J.S., Hitt, M.A., Hoskisson, R.E., and Ireland, R.D. (2001) 'Resource complementarity in business combinations: Extending the logic to organizational alliances', Journal of Management, Vol. 27, No. 6, pp. 679-90. 
Haspeslagh, P.C. and Jemison, D.B. (1991) Managing acquisitions: Creating value through corporate renewal, Free Press, New York.

Hise, R.T. (1991) 'Evaluating marketing assets in mergers and acquisitions', The Journal of Business Strategy, Vol. 12, No. 4, pp. 46-51.

Hitt, M.A., Harrison, J. S., and Ireland, R. D. (2001) Mergers and acquisitions: A guide to creating value for stakeholders, Oxford University Press, New York.

Homburg, C. and Bucerius, M. (2005) 'A marketing perspective on mergers and acquisitions: How marketing integration affects postmerger performance', Journal of Marketing, Vol. 69, No. 1, pp. 95-113.

Homburg, C. and Bucerius, M. (2006) 'Is speed of integration really a success factor of mergers and acquisitions? An analysis of the role of internal and external relatedness', Strategic Management Journal, Vol. 27, No. 4, pp. 347-67.

Hooley, G.J., Greenley, G.E., Cadogan, J.W., and Fahy, J. (2005) 'The performance impact of marketing resources', Journal of Business Research, Vol. 58, No. 1, pp. 18-27.

Howell, R.A. (1970) 'Plan to integrate your acquisitions', Harvard Business Review, Vol. 48, No. 6, pp. 66-76.

Huang, C.T.W. and Kleiner, B.H. (2004) 'New developments concerning managing mergers and acquisitions', Management Research News, Vol. 27, No. 4/5, pp. 54-63.

Inkpen, A. and Tsang, E. (2005) 'Social capital, networks and knowledge transfer', Academy of Management Review, Vol. 30, No. 1, pp. 146-65.

Jaju, A., Joiner, C., and Reddy, S.K. (2006) 'Consumer evaluations of corporate brand redeployments', Journal of the Academy of Marketing Science, Vol. 34, No. 2, pp. 206-15.

Jean, R.-J.B., Sinkovics, R.R., and Cavusgil, S.T. (2010) 'Enhancing international customer-supplier relationships through IT resources: A study of Taiwanese electronics suppliers', Journal of International Business Studies, Vol. 41, No. 7, pp. $1-22$.

Kahn, K.B. (2001) 'Market orientation, interdepartmental integration, and product development performance', Journal of Product Innovation Management, Vol. 18, No. 5, pp. 314-23.

Kahn, K.B. and Mentzer, J.T. (1998) 'Marketing's integration with other departments', Journal of Business Research, Vol. 42, No. 1, pp. 53-62.

Kim, J.-Y. and Finkelstein, S. (2009) 'The effects of strategic and market complementarity on acquisition performance: Evidence from the U.S. Commercial banking industry, 1989-2001', Strategic Management Journal, Vol. 30, No. 6, pp. 617-46.

King, D.R., Dalton, D.R., Daily, C.M., and Covin, J.G. (2004) 'Meta-analyses of postacquisition performance: Indications of unidentified moderators', Strategic Management Journal, Vol. 25, No. 2, pp. 187-200.

Krishnan, R.A., Joshi, S., and krishnan, H. (2004) 'The influence of mergers on firms' product-mix strategies ', Strategic Management Journal, Vol. 25, No. 6, pp. 587611.

Kroon, D., Noorderhaven, N., and Leufkens, A. (2008) 'Organizational identification and cultural differences: Explaining employee attitudes and behavioral intentions during post-merger integration', in Cooper, C.L. and Finkelstein, S. (Eds.), Advances in mergers and acquisitions Vol. 8, Emerald Group Publishing Limited, Bingley, pp. $19-42$.

Kusstatscher, V. (2005) 'The management of communication and interpersonal relationships in the M\&A context', in Morrow, T., Loane, S., Bell, J., and Wheeler, C. (Eds.), International business in an enlarging Europe, Palgrave Macmillan, Houndsmills, U.K., pp. 115-34. 
Kusstatscher, V. (2006) 'Cultivating positive emotions in mergers and acquisitions', in Cooper, C.L. and Finkelstein, S. (Eds.), Advances in mergers and acquisitions Vol. 5, Elsevier JAI, Amsterdam, The Netherlands, pp. 91-103.

Laamanen, T. and Keil, T. (2008) 'Performance of serial acquirers: Toward an acquisition program perspective', Strategic Management Journal, Vol. 29, No. 6, pp. 663-72.

Lakshman, C. (2011) 'Postacquisition cultural integration in mergers \& acquisitions: A knowledge-based approach', Human Resource Management, Vol. 50, No. 5, pp. 605-23.

Lambkin, M. and Muzellec, L. (2008) 'Rebranding in the banking industry following mergers and acquisitions', International Journal of Bank Marketing, Vol. 26, No. 5, pp. 328-52.

Lancaster, G. (1993) 'Marketing and engineering: Can there ever be synergy?', Journal of Marketing Management, Vol. 9, No. 2, pp. 141-53.

Larsson, R. and Finkelstein, S. (1999) 'Integrating strategic, organizational, and human resource perspectives on mergers and acquisitions: A case survey of synergy realization', Organization Science, Vol. 10, No. 1, pp. 1-26.

Li, P.-C. and Chen, Y.-C. (2010) 'How does social orientation influence R\&D-marketing collaboration?', Asia Pacific Journal of Management, Vol. online first, (DOI: 10.1007/s10490-010-9195-7).

Lien, L.B., Klein, P.G., Cary, L.C., and Finkelstein, S. (2006) 'Relatedness and acquirer performance', Advances in mergers and acquisitions Vol. Volume 5, JAI, pp. 9-23.

Lin, N., Cook, K., and Burt, R. (Eds.) (2006) Social capital: Theory and research. Transaction Publishers, New Jersey.

Lockett, A., Thompson, S., and Morgenstern, U. (2009) 'The development of the resourcebased view of the firm: A critical appraisal', International Journal of Management Reviews, Vol. 11, No. 1, pp. 9-28.

Longbottom, D., Mayer, R., and Casey, J. (2000) 'Marketing, total quality management and benchmarking: Exploring the divide', Journal of Strategic Marketing, Vol. 8, No. 4, pp. 327-40.

Marks, M. and Mirvis, P. (2011a) 'Merge ahead: A research agenda to increase merger and acquisition success', Journal of Business and Psychology, Vol. 26, No. 2, pp. 161-68.

Marks, M.L. and Mirvis, P.H. (2000) 'Managing mergers, acquisitions, and alliances: Creating an effective transition structure', Organizational Dynamics, Vol. 28, No. 3, pp. 35-47.

Marks, M.L. and Mirvis, P.H. (2011b) 'A framework for the human resources role in managing culture in mergers and acquisitions', Human Resource Management, Vol. 50, No. 6, pp. 859-77.

Marmenout, K. (2011) 'Peer interaction in mergers: Evidence of collective rumination', Human Resource Management, Vol. 50, No. 6, pp. 783-808.

Maruca, R.F. (1996) 'Look for marketing synergies', Harvard Business Review, Vol. 74, No. 6, pp. 10-11.

Meglio, O. and Risberg, A. (2011) 'The (mis) management of M\&A performance - a systematic narrative literature review', Scandinavian Journal of Management, Vol. 27, pp. 418-33.

Meschi, P.-X. and Metais, E. (2006) 'International acquisition performance and experience: A resource-based view. Evidence from french acquisitions in the United States (1988-2004)', Journal of International Management, Vol. 12, No. 4, pp. 430-48.

Morosini, P., Shane, S., and Singh, H. (1998) 'National cultural distance and cross-border acquisition performance', Journal of International Business Studies, Vol. 29, No. 1, pp. 137-58. 
Nahapiet, J. and Ghoshal, S. (1998) 'Social capital, intellectual capital, and the organizational advantage', The Academy of Management Review, Vol. 23, No. 2, pp. 242-66.

Nick, W.-J. (2008) 'The networked firm: A framework for rbv', The Journal of Management Development, Vol. 27, No. 2, pp. 214.

Nils Bohlin, E.D., and Sue Thomson (1998) 'Successful post-merger integration: Realising the synergies', PRISM, No. 1, pp. 1-6.

Orit, G., Charles, O., and Sam, R. (2003) 'Achieving an M\&A's strategic goals at maximum speed for maximum value', Strategy \& Leadership, Vol. 31, No. 3, pp. 35-41.

Palmatier, R.W., Miao, C.F., and Fang, E. (2007) 'Sales channel integration after mergers and acquisitions: A methodological approach for avoiding common pitfalls', Industrial Marketing Management, Vol. 36, No. 5, pp. 589-603.

Parry, M.E. and Song, X.M. (1993) 'Determinants of R\&D--marketing integration in hightech Japanese firms', Journal of Product Innovation Management, Vol. 10, No. 1, pp. 4-22.

Prasad, V.K., Ramamurthy, K., and Naidu, G.M. (2001) 'The influence of internetmarketing integration on marketing competencies and export performance', Journal of International Marketing, Vol. 9, No. 4, pp. 82-110.

Puranam, P., Singh, H., and Zollo, M. (2003) 'A bird in the hand or two in the bush?: Integration trade-offs in technology-grafting acquisitions', European Management Journal, Vol. 21, No. 2, pp. 179-84.

Putnam, R.D. (1993) 'The prosperous community', The American Prospect, Vol. 4, No. 13, pp. 1-11.

Richey, R.G., Kiessling, T.S., Tokman, M., and Dalela, V. (2008) 'Market growth through mergers and acquisitions: The role of the relationship marketing manager in sustaining performance', Industrial Marketing Management, Vol. 37, No. 4, pp. 394-406.

Rouzies, D., Anderson, E., Kohli, A.K., Michaels, R.E., Weitz, B.A., and Zoltners, A.A. (2005) 'Sales and marketing integration: A proposed framework', Journal of Personal Selling \& Sales Management, Vol. 25, No. 2, pp. 113-22.

Ruekert, R.W. and Walker Jr, O.C. (1987) 'Marketing's interaction with other functional units: A conceptual framework and empirical evidence', Journal of Marketing, Vol. 51, No. 1, pp. 1-19.

Saunders, M.N.K., Altinay, L., and Riordan, K. (2009) 'The management of post-merger cultural integration: Implications from the hotel industry', Service Industries Journal, Vol. 29, No. 10, pp. 1359-75.

Schoenberg, R. (2006) 'Measuring the performance of corporate acquisitions: An empirical comparison of alternative metrics', British Journal of Management, Vol. 17, No. 4, pp. 361-70.

Schweiger, D.M. (2002) M\&A integration: A framework for executives and managers, McGraw-Hill Companies, New York.

Schweiger, D.M. and Goulet, P.K. (2000) 'Integrating mergers and acquisitions: An international research review', Advances in mergers and acquisitions Vol. Volume 1, JAI, pp. 61-91.

Schweiger, D.M., Ivancevich, J.M., and Power, F.R. (1987) 'Executive actions for managing human resources before and after acquisition', Academy of Management Executive, Vol. 1, No. 2, pp. 127-38.

Schweiger, D.M. and Very, P. (2003) 'Creating value through merger and acquisition integration', Advances in mergers and acquisitions Vol. Volume 2, JAI, pp. 1-26. 
Schweizer, L. (2005) 'Organizational integration of acquired biotechnology companies into pharmaceutical companies: The need for a hybrid approach', Academy of Management Journal, Vol. 48, No. 6, pp. 1051-74.

Schweizer, L. and Patzelt, H. (2012) 'Employee commitment in the post-acquisition integration process: The effect of integration speed and leadership', Scandinavian Journal of Management, Vol. 28, No. 4, pp. 298-310.

Shimizu, K., Hitt, M.A., Vaidyanath, D., and Pisano, V. (2004) 'Theoretical foundations of cross-border mergers and acquisitions: A review of current research and recommendations for the future', Journal of International Management, Vol. 10, No. 3, pp. 307-53.

Shrader, R.C. (2001) 'Collaboration and performance in foreign markets: The case of young high-technology manufacturing firms', Academy of Management Journal, Vol. 44, pp. 45-60.

Sinkovics, R.R., Zagelmeyer, S., and Kusstatscher, V. (2011) 'Between merger and syndrome: The intermediary role of emotions in four cross-border M\&As', International Business Review, Vol. 20, No. 1, pp. 27-47.

Sirower, M.L. and Lipin, S. (2003) 'Investor communications: New rules for M\&A success. (cover story)', Financial Executive, Vol. 19, No. 1, pp. 26-30.

Sirower, M.L. and Sahni, S. (2006) 'Avoiding the "synergy trap": Practical guidance on M\&A decisions for ceos and boards', Journal of Applied Corporate Finance, Vol. 18, No. 3, pp. 83-95.

Song, X.M., Montoya-Weiss, M.M., and Schmidt, J.B. (1997) 'Antecedents and consequences of cross-functional cooperation: A comparison of $\mathrm{R} \& \mathrm{D}$, manufacturing, and marketing perspectives', Journal of Product Innovation Management, Vol. 14, No. 1, pp. 35-47.

Srivastava, R.K., Shervani, T.A., and Fahey, L. (1999) 'Marketing, business processes, and shareholder value: An organizationally embedded view of marketing activities and the discipline of marketing', Journal of Marketing, Vol. 63, No. 4, pp. 168-79.

Stahl, G.K., Larsson, R., Kremershof, I., and Sitkin, S.B. (2011) 'Trust dynamics in acquisitions: A case survey', Human Resource Management, Vol. 50, No. 5, pp. 575-603.

Stahl, G.K. and Mendenhall, M.E. (Eds.) (2005) Mergers and acquisitions: Managing culture and human resources. Stanford Business Books, Stanford, CA.

Stahl, G.K. and Voigt, A. (2008) 'Do cultural differences matter in mergers and acquisitions? A tentative model and examination', Organization Science, Vol. 19, No. 1, pp. 16076.

Stank, T.P., Daugherty, P.J., and Ellinger, A.E. (1999) 'Marketing/logistics integration and firm performance', International Journal of Logistics Management, Vol. 10, No. 1, pp. 11-25.

Sudarsanam, S. (2003) Creating value from mergers and acquisitions: The challenges, Pearson Education, London.

Tanure, B., Cancado, V.L., Duarte, R.G., and Muylder, C.F.d. (2009) 'The role of national culture in mergers and acquisitions', Latin American Business Review, Vol. 10, No. 2/3, pp. 135-59.

Teerikangas, S., Véry, P., and Pisano, V. (2011) 'Integration managers' value-capturing roles and acquisition performance', Human Resource Management, Vol. 50, No. 5, pp. 651-83.

Tsai, W. (2000) 'Social capital, strategic relatedness and the formation of intraorganizational linkages', Strategic Management Journal, Vol. 21, No. 9, pp. 925-39. 
Uhlenbruck, K., Hitt, M.A., and Semadeni, M. (2006) 'Market value effects of acquisitions involving internet firms: A resource-based analysis', Strategic Management Journal, Vol. 27, No. 10, pp. 899-913.

Vanitha, S., Feisal, M., and John, H. (2008) 'Value creation following merger and acquisition announcements: The role of strategic emphasis alignment', Journal of Marketing Research, Vol. 45, No. 1, pp. 33-47.

Vasilaki, A. (2011) 'The relationship between transformational leadership and postacquisition performance', International Studies of Management \& Organization Vol. 41, No. 3, pp. 42-58.

Very, P. and Lubatkin, M. (1996) 'A cross-national assessment of acculturative stress in recent European mergers', International Studies of Management \& Organization, Vol. 26, No. 1, pp. 59-86.

Walker, G., Bruce, K., and Weijian, S. (1997) 'Social capital, structural holes and the formation of an industry network', Organization Science, Vol. 8, No. 2, pp. 109-25.

Wan, W.P. and Yiu, D.W. (2009) 'From crisis to opportunity: Environmental jolt, corporate acquisitions, and firm performance', Strategic Management Journal, Vol. 30, No. 7, pp. 791-801.

Wang, L. and Zajac, E.J. (2007) 'Alliance or acquisition? A dyadic perspective on interfirm resource combinations', Strategic Management Journal, Vol. 28, No. 13, pp. 1291317.

Wang, Q. and Boateng, A. (2007) 'Cross-border M\&As by Chinese firms: An analysis of strategic motivation and performance', International Management Review, Vol. 3, No. 4, pp. 19-29.

Weber, J.A. and Dholakia, U.M. (2000) 'Including marketing synergy in acquisition analysis: A step-wise approach', Industrial Marketing Management, Vol. 29, No. 2, pp. 157-77.

Weber, Y. (2011) 'Guest editor's introduction: Managing mergers and acquisitions implementation and integration', International Studies of Management \& Organization, Vol. 41, No. 3, pp. 3-8.

Weber, Y. and Fried, Y. (2011) 'Guest editors' note: The dynamic of employees' reactions during postmerger integration process', Human Resource Management, Vol. 50, No. 6, pp. 777-81.

Weber, Y., Rachman-Moore, D., and Tarba, S.Y. (2012) 'HR practices during post-merger conflict and merger performance', International Journal of Cross Cultural Management, Vol. 12, No. 1, pp. 73-99.

Weber, Y., Shenkar, O., and Raveh, A. (1996) 'National and corporate cultural fit in mergers/acquisitions: An exploratory study', Management Science, Vol. 42, No. 8, pp. 1215-28.

Weber, Y. and Tarba, S. (2011) 'Exploring integration approach in related mergers: Postmerger integration in the high-tech industry', International Journal of Organizational Analysis, Vol. 19, No. 3, pp. 202-21.

Weber, Y. and Tarba, S.Y. (2010) 'Human resource practices and performance of mergers and acquisitions in israel', Human Resource Management Review, Vol. 20, No. 3, pp. 203-11.

Weber, Y., Tarba, S.Y., and Bachar, Z.R. (2011) 'Mergers and acquisitions performance paradox: The mediating role of integration approach', European Journal of International Management, Vol. 5, No. 4, pp. 373-93.

Weber, Y., Tarba, S.Y., and Reichel, A. (2011) 'A model of the influence of culture on integration approaches and international mergers and acquisitions performance', International Studies of Management \& Organization Vol. 41, No. 3, pp. 9-24. 
Weber, Y., Teerikangas, S., Rouzies, A., and Tarba, S.Y. (2012) 'Mergers and acquisitions management: New directions. Editorial', European Journal of International Management, Vol. 6, No. 4, pp. 363-67.

Weiss, J. and Hughes, J. (2005) 'Want collaboration?', Harvard Business Review, Vol. 83, No. 3, pp. 93-101.

Yli-Renko, H., Autio, E., and Sapienza, H.J. (2001) 'Social capital, knowledge acquisition, and knowledge exploitation in young technology-based firms', Strategic Management Journal, Vol. 22, No. 6-7, pp. 587-613.

Yong, L. and Aguilera, R.V. (2008) 'Target director turnover in acquisitions: A conceptual framework', Corporate Governance: An International Review, Vol. 16, No. 6, pp. 492-503.

Yung-Ming, C. (2006) 'Determinants of FDI mode choice: Acquisition, brownfield, and greenfield entry in foreign markets', Canadian Journal of Administrative Sciences, Vol. 23, No. 3, pp. 202-20.

Zhanwen, Z. and Haifeng, H. (2007) 'The cultural integration in the process of cross-border mergers and acquisitions', International Management Review, Vol. 3, No. 2, pp. 4044.

Zollo, M. and Meier, D. (2008) 'What is M\&A performance?', Academy of Management Perspectives, Vol. 22, No. 3, pp. 55-77.

Zollo, M. and Singh, H. (2004) 'Deliberate learning in corporate acquisitions: Postacquisition strategies and integration capability in u.S bank mergers ', Strategic Management Journal, Vol. 25, pp. 1233-56.

Zou, H. and Simpson, P. (2008) 'Cross-border mergers and acquisitions in China: An industry panel study, 1991-2005', Asia Pacific Business Review, Vol. 14, No. 4, pp. 491-512. 
Figure 1: Conceptual model of marketing integration in the M\&A context

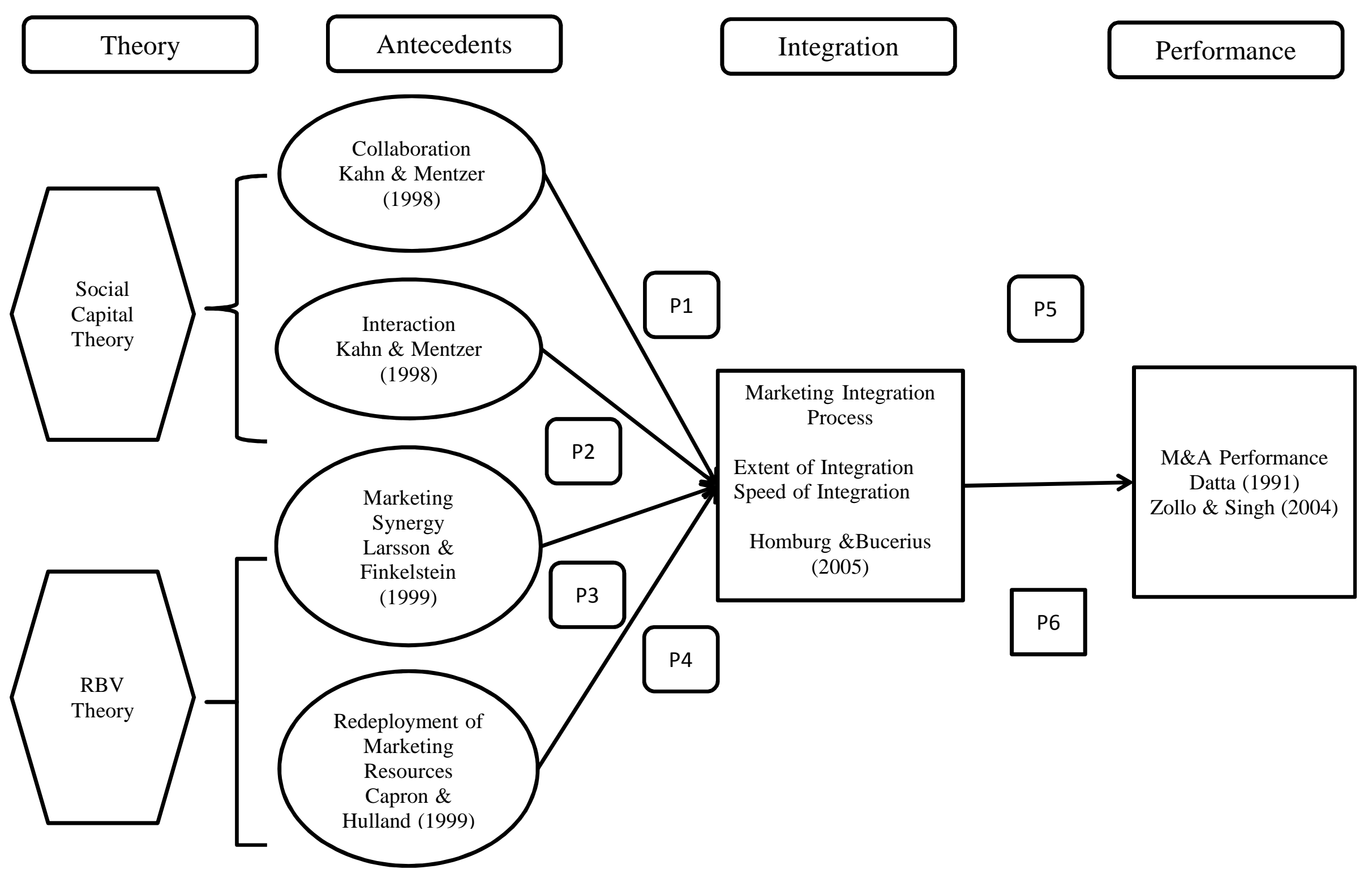


Table 1: Empirical Research in M\&A Integration-Related Studies

\begin{tabular}{|c|c|c|c|c|c|}
\hline Author (s) & $\begin{array}{l}\text { Locations / Type of } \\
\text { M\&A/ Period / } \\
\text { Industry }\end{array}$ & $\begin{array}{l}\text { Data Resource / Collection } \\
\text { Method }\end{array}$ & Objectives of Study & $\begin{array}{l}\text { Statistical } \\
\text { Analysis }\end{array}$ & Results \\
\hline $\begin{array}{l}\text { Capron and } \\
\text { Hulland } \\
\text { (1999) }\end{array}$ & $\begin{array}{l}\text {-US and Europe } \\
\text {-Horizontal } \\
\text { Acquisitions } \\
\text {-Period 1988-1992 } \\
\text {-Multiple Industry }\end{array}$ & $\begin{array}{l}\text {-The International Merger Year- } \\
\text { book }(1990,1991,1992), \text { M\&A } \\
\text { source book, M\&A International } \\
\text { (1991,1992,1992) and Fusions et } \\
\text { Acquisitions Magazine } \\
(1989,1990,1991,1992) \\
\text {-Ten interviews } \\
\text {-Final sample n = 253 } \\
\text {-Survey }\end{array}$ & $\begin{array}{l}\text {-To investigate the degree of } \\
\text { redeployment of three marketing } \\
\text { resources across merging firms } \\
\text { following horizontal acquisitions } \\
\text {-To examine the impact of such } \\
\text { resource redeployments on } \\
\text { subsequent performance. }\end{array}$ & $\begin{array}{l}\text { Correlations } \\
\text { Regression } \\
\text { Model }\end{array}$ & $\begin{array}{l}\text {-Acquirer and the target firm frequently redeploy } \\
\text { their resources } \\
\text {-Immobile resources are more likely to be } \\
\text { redeployed from target firm to the acquirer firm }\end{array}$ \\
\hline $\begin{array}{l}\text { Cording et } \\
\text { al.(2008) }\end{array}$ & $\begin{array}{l}\text {-US } \\
\text {-Only horizontal } \\
\text { acquisitions } \\
\text {-Applied to both } \\
\text { acquirer and target } \\
\text { firms } \\
\text {-Period 1997-2001 }\end{array}$ & $\begin{array}{l}\text {-Securities Data Corporation's } \\
\text { (SDC) } \\
\text {-Survey } \\
\text {-Final sample, } \mathrm{n}=137\end{array}$ & $\begin{array}{l}\text {-To examine how causal ambiguity } \\
\text { is related to performance outcomes } \\
\text { in acquisitions by identifying a } \\
\text { mechanism that reduces intra-firm } \\
\text { linkage ambiguity }\end{array}$ & $\begin{array}{l}\text { Partial Least } \\
\text { Square } \\
\text { (PLS Graph, } \\
\text { version 3.0) }\end{array}$ & $\begin{array}{l}\text {-Intermediate goals strongly reduce the intra-firm } \\
\text { linkage ambiguity therefore allow acquisition into } \\
\text { a more easily manageable situation } \\
\text {-Intermediate goal achievement fully mediates the } \\
\text { relationship between integration decisions and } \\
\text { acquisition performance }\end{array}$ \\
\hline Datta (1991) & $\begin{array}{l}\text {-Acquisitions in US } \\
\text {-Manufacturing and } \\
\text { Mining sectors } \\
\text {-Period 1980-1984 }\end{array}$ & $\begin{array}{l}\text {-Survey } \\
\text {-Quarterly issues of M\&A } \\
\text {-Sample } 703 \\
\text {-Final sample } \mathrm{n}=173 \\
\text { acquisitions }\end{array}$ & $\begin{array}{l}\text {-To examine the impact of } \\
\text { differences in rewards and } \\
\text { management styles on post- } \\
\text { acquisition performance } \\
\text {-To identify whether the } \\
\text { relationship depends on the extent } \\
\text { of post-acquisition integration }\end{array}$ & $\begin{array}{l}\text { Correlations } \\
\text { Regression }\end{array}$ & $\begin{array}{l}\text {-Compatibility of management styles is important } \\
\text { to improve acquisition performance } \\
\text {-Differences in top management styles have a } \\
\text { negative impact on performance in acquisitions } \\
\text { characterized by both high and low levels of post- } \\
\text { acquisition integration. } \\
\text {-No such relationship was observed n either the } \\
\text { high or low integration subgroups. }\end{array}$ \\
\hline $\begin{array}{l}\text { Homburg and } \\
\text { Bucerius } \\
(2005)\end{array}$ & $\begin{array}{l}\text {-Germany, Austria } \\
\text { and Switzerland } \\
\text {-Horizontal M\&A } \\
\text {-Period of 1996-1999 } \\
\text {-Multiple industries }\end{array}$ & $\begin{array}{l}\text {-Survey } \\
\text {-M\&A Database University of St. } \\
\text { Gallen Switzerland and M\&A } \\
\text { related European Business } \\
\text { Magazines } \\
\text {-Final sample, } \mathrm{n}=232\end{array}$ & $\begin{array}{l}\text {-To investigate how the marketing } \\
\text { integration process affects } \\
\text { integration outcomes } \\
\text {-To investigate how these } \\
\text { relationships are affected by certain } \\
\text { moderators } \\
\text {-To analyze the importance of } \\
\text { market-related performance for } \\
\text { M\&A performance }\end{array}$ & $\begin{array}{l}\text { Correlations } \\
\text { LISREL } 8\end{array}$ & $\begin{array}{l}\text {-Marketing integration process positively drives } \\
\text { M\&A performance } \\
\text {-Marketing issues more important than cost } \\
\text { savings }\end{array}$ \\
\hline
\end{tabular}




\begin{tabular}{|c|c|c|c|c|c|}
\hline $\begin{array}{l}\text { Larsson and } \\
\text { Finkelstein } \\
\text { (1999) }\end{array}$ & $\begin{array}{l}\text {-US and Europe } \\
\text { Database: case } \\
\text { catalogues, reference } \\
\text { lists, computer } \\
\text { searches and direct } \\
\text { inquiry }\end{array}$ & -112 empirical case studies & $\begin{array}{l}\text {-To develop and test a model that } \\
\text { synthesizes theoretical perspectives } \\
\text { on strategic combination, } \\
\text { organizational integration, HRM } \\
\text { and financial performance } \\
\text {-To examine the mechanisms of } \\
\text { synergy realization }\end{array}$ & $\begin{array}{l}\text { Correlations } \\
\text { Structural } \\
\text { Equation } \\
\text { Modeling } \\
\text { (LISREL 7) }\end{array}$ & $\begin{array}{l}\text {-Organizational integration was strongest } \\
\text { predictor of synergy realization } \\
\text {-Employee resistance was negatively associated } \\
\text { with synergy realization }\end{array}$ \\
\hline Schweizer (2005) & $\begin{array}{l}\text {-Database: } \\
\text { Pharmaceuticals and } \\
\text { Biotech companies in } \\
\text { 1990s in Europe } \\
\text { (acquirers) and US } \\
\text { (target) }\end{array}$ & $\begin{array}{l}\text {-Five in-depth case studies } \\
\text {-Semi-structured interviews }\end{array}$ & $\begin{array}{l}\text {-To investigate how the acquiring } \\
\text { pharmaceutical companies integrate } \\
\text { acquired biotech companies to gain } \\
\text { access to their know-how and } \\
\text { technologies }\end{array}$ & $\begin{array}{l}\text {-Matrix } \\
\text { technique for } \\
\text { comparative } \\
\text { analysis } \\
\text {-Comprehensive } \\
\text { case description }\end{array}$ & $\begin{array}{l}\text {-unique contribution to } M \& A \text { literature } \\
\text {-It is suggested to focus on the rapid integration of } \\
\text { all non-R\&D-related functions of the acquired } \\
\text { business } \\
-R \& D \text { related functions should retain a high } \\
\text { degree of autonomy } \\
\text {-Biotech culture is worth preserving }\end{array}$ \\
\hline $\begin{array}{l}\text { Richey et al. } \\
\text { (2008) }\end{array}$ & $\begin{array}{l}\text {-US } \\
\text {-Across } 71 \text { industries }\end{array}$ & $\begin{array}{l}\text {-Survey } \\
\text {-Ernst and Young Database } \\
\text {-Final sample, } \mathrm{n}=104\end{array}$ & $\begin{array}{l}\text {-To suggest key success factors } \\
\text { such as relationship marketing } \\
\text { manager retention } \\
\text {-To assess the impact of firms' } \\
\text { post-acquisition performance } \\
\text { through employee-mediated } \\
\text { relationships }\end{array}$ & $\begin{array}{l}\text { Hierarchical } \\
\text { linear regression }\end{array}$ & $\begin{array}{l}\text { - The retention of relationship marketing } \\
\text { managers could enhance the chance of the } \\
\text { combined firm's survival } \\
\text {-More attention is needed to avoid productivity } \\
\text { decreases }\end{array}$ \\
\hline $\begin{array}{l}\text { Vanitha et al. } \\
\text { (2008) }\end{array}$ & $\begin{array}{l}\text {-US } \\
\text {-Multiple industries } \\
\text {-Period of 1990-2001 }\end{array}$ & $\begin{array}{l}\text {-Event study } \\
\text {-Final sample, } \mathrm{n}=206 \\
\text {-SIC and Thomson M\&A } \\
\text { database }\end{array}$ & $\begin{array}{l}\text {-Introduces strategic emphasis } \\
\text { alignment as construct } \\
\text {-To show that similarity and } \\
\text { complementarity create value } \\
\text {-To show how marketing resources } \\
\text { (advertising) influence M\&A value } \\
\text { creation }\end{array}$ & $\begin{array}{l}\text { Ordinary least } \\
\text { square }\end{array}$ & $\begin{array}{l}\text { Strategic emphasis alignment had positive results } \\
\text { for the consolidation of all industries involved } \\
\text { Positive effect of similarity of resources on } \\
\text { consolidation and positive effect of } \\
\text { complementarity on diversification in M\&A } \\
\text { transactions }\end{array}$ \\
\hline $\begin{array}{l}\text { Weber et al. } \\
\text { (2011) }\end{array}$ & $\begin{array}{l}\text {-Israel } \\
\text {-Period of cases, } \\
2004-2006\end{array}$ & $\begin{array}{l}\text {-Survey } \\
\text {-Final sample, } \mathrm{n}=52 \\
\text {-Archive of the Israel Antitrust } \\
\text { Authority }\end{array}$ & $\begin{array}{l}\text {-To explore the role of the } \\
\text { integration approach in the } \\
\text { implementation of M\&As. } \\
\text {-To suggest a revised framework } \\
\text { for integration approach to better } \\
\text { explain integration effectiveness } \\
\text {-usage of fit between the } \\
\text { recommended and the actually } \\
\text { implemented integration approach } \\
\text { to better explain integration } \\
\text { effectiveness }\end{array}$ & $\begin{array}{l}\text { Inter- } \\
\text { correlations } \\
\text { Through } \\
\text { regression } \\
\text { analysis }\end{array}$ & $\begin{array}{l}\text { Findings suggest that the fit of the integration } \\
\text { approach is positively related to integration } \\
\text { effectiveness and mediates its relationship with } \\
\text { synergy potential and cultural differences }\end{array}$ \\
\hline
\end{tabular}




\begin{tabular}{|l|l|l|l|l|l|}
\hline $\begin{array}{l}\text { Zollo and Singh } \\
(2004)\end{array}$ & $\begin{array}{l}\text {-US } \\
\text {-Commercial banking } \\
\text { industry } \\
\text {-Period 1986-1994 }\end{array}$ & $\begin{array}{l}\text {-Interviews and survey } \\
\text {-Final sample 51 from 250 banks }\end{array}$ & $\begin{array}{l}\text {-To examine the extent of acquired } \\
\text { firm integration and the extent to } \\
\text { which it replaces the firm's top } \\
\text { management team }\end{array}$ & $\begin{array}{l}\text { Correlation } \\
\text { Regression } \\
\text { Ordinary Least } \\
\text { Square }\end{array}$ & $\begin{array}{l}\text { Firms could develop collective competence by not } \\
\text { only accumulating experience but also investing } \\
\text { time and effort in activities that require higher } \\
\text { cognitive effort }\end{array}$ \\
\hline
\end{tabular}

